\title{
Editorial
}

\section{RESPETO DE LA AUTONOMÍA UNIVERSITARIA}

Es de conocimiento público que el gobierno está queriendo imponer una nueva Ley Universitaria, se dice con la finalidad de mejorar aspectos administrativos y académicos de los procesos que en las Universidades se desarrollan; ¿no fue acaso el mismo gobierno quien impuso el DL 882, que atentaba contra la Ley Universitaria del año 1983?.

La ley Universitaria No 23733 promulgada el 9 de diciembre de 1983, puede tener muchos defectos, pero es un documento emitido por consenso donde se realizaron las respectivas consultas a los autores principales, que son justamente los que definen el actuar en los claustros universitarios y en base a su propio actuar asesoran a los entes de gobierno en materia de educación superior. ¿Qué está sucediendo en ésta oportunidad?, se estuvo queriendo imponer como bien diríamos a "paso de polka”, o mejor dicho a una velocidad increíble una nueva ley, sin la consulta a los entes técnicos en materia de educación superior, nuevo documento creado por los miembros del congreso que en aspectos de "educación", dejan mucho que desear, sino observemos día a día los titulares de los diarios, inclusive de los más serios, en los cuales vemos el actuar de nuestros insignes padres de la patria, reflejando actos de tremenda falta de educación, respeto a las buenas costumbres e inclusive tremendos actos de corrupción.

Esta forma de actuar por parte del Congreso de la Republica, a través de la Comisión de Educación (quienes son los responsables de dicho proyecto de Ley), vulnera definitivamente la Autonomía Universitaria, claramente definida en la Constitución Política del Perú, queriendo imponer una situación de control por parte del gobierno con la finalidad política de imposición de normas educativas y dependencia administrativa por parte del gobierno hacia la Universidad; recordemos que la Universidad es el institución más creativa en lo referente al avance de la ciencia y no puede ser maniatada en su desarrollo, además es la institución que crea las nuevas generaciones de profesionales que servirán al país, donde la libertad de pensamiento y acción debe ser fundamento de su actuar.

Reconocemos que existen problemas con la actual ley, pero ¿no son los propios docentes universitarios los que tienen que proponer las enmiendas a éstos problemas?; hay que dejar muy en claro que la Universidad no se opone al cambio ni a la modernización educativa, pero esto se debe cumplir en un marco de libertad sin intervencionismo, lo que demostraría una clara transparencia que se podría plasmar en un documento nuevo acorde con las normas que rigen el mundo moderno bajo los principios de libertad y equidad y no en base a una política de gobierno.

La autonomía universitaria no debe ser vulnerada, pues gracias a ella la Universidad siempre será un foco de producción científico y técnico, dentro de un marco de equidad, progreso y ética que solamente lo puede lograr en base a su propia autonomía. 